\title{
Member Organization
}

National Cancer Institute

\section{Source}

National Cancer Institute. Member Organization. NCI Thesaurus. Code C79888.

A grouping of individuals and functions into a single unit that is part of a larger group such as a cooperative group, research network, consortium, etc. 